\title{
ASEAN Commitment to Sustainable Development in the Regional International Environmental Law Perspective
}

\author{
Andreas Pramudianto \\ University of Indonesia, Jakarta , Indonesia
}

\begin{abstract}
The World Commission on Environment and Development in its report entitled "Our Common Future” has put forward the idea of sustainable development which is also an important part of the development of regional environmental law in Southeast Asia. In 1985 ASEAN Agreement on the Nature and Natural Resources has put sustainable development for the first time in ASEAN's treaty. Sustainable development continues to grow through the 1987 Jakarta Resolution on Sustainable Development agreed upon by the leaders of ASEAN. This research will look at the importance of sustainable development as part of the regional environmental international law concept and how it has grown in ASEAN today. The purpose of this research is to know the various international agreements both soft law and hard law that puts sustainable development as an important element. The results show that sustainable development has become an integral part of the regional international environmental legal system in ASEAN. A provisional conclusion shows that ASEAN's commitment to sustainable development has greatly improved the success of implementing environmental policies at the ASEAN level.
\end{abstract}

Keywords: sustainable development, ASEAN, international environmental law regional, international agreements, soft law and hard law

\section{Introduction}

ASEAN is one of the regional international organizations that has developed compared to the establishment of this organization through the Bangkok Declaration of 1967. Over its 38 years, ASEAN has operated without a formal charter (Severino, 2005, p. 3). The approval of the ASEAN Charter in 2007 has asserted a more formal organizational position than simply gathering into a rule-based organization with legal personality capacity and tends to be centralistic (LIN, 2010). With this change ASEAN will be able to make various international treaties with other international legal subjects (Pramudianto, 2017, p. 267).

ASEAN, as an influential organization in Southeast Asia, is also experiencing problems, especially in issues that are developing today. The issue of Rohingya conflict, the existence of ISIS (Islamic State) in the Philippines, and the issue of South China Sea conflict are issues involving several ASEAN countries. In issues such as the South China Sea conflict, it sometimes has sharp differences in its foreign policy, especially defense and security. The Philippines, Brunei, Malaysia, and Vietnam are the countries that have spent their focus on border issues in the South China Sea facing China as the superpower in East Asia today.

Andreas Pramudianto, SH, M.Si, lecturer, Study Programe on Environmental Science, School of the Environmental Science and Departement of International Relations, Faculty of Social and Politic Science, University of Indonesia, Jakarta , Indonesia. 
Sustainable development as one of the vision of ASEAN seems to be experiencing obstacles in the effort to achieve its goals. The South China Sea conflict issue, the Rohingya conflict, and the existence of ISIS in the Philippines are an important obstacle in achieving sustainable development, especially in achieving the target of Sustainable Development Goals (SDGs). Defense and security is a crucial issue to be taken into account for ASEAN in realizing sustainable development in the Southeast Asian region.

Sustainable development, which has been affirmed by the Environment and Development Commission through its report of "Our Common Future" in 1988, has now grown much more meaningful. The establishment of the UN Commission on Sustainable Development (UNCSD) has provided a wider nuance with much more developed dynamics today. UNCSD, which is the result of the 1992 Rio Summit, has encouraged more serious efforts to achieve the Millennium Summit 2000 outcome that confirms the Millennium Development Goals (MDGs) 2000-2015 or its successor which is the result of UNGA ( United Nations General Assembly ) 2015, Sustainable Development Goals (SDGs) 2015-2030.

The problem is: Does ASEAN also have a similar commitment to the dynamics of global international relations, especially in sustainable development? How does ASEAN address the existence of the concept of sustainable development and how does ASEAN develop the concept of sustainable development in its dealings through the resulting documents? Furthermore, will ASEAN be able to influence regional international law in Southeast Asia through the concept of sustainable development? This paper will try to see ASEAN's perspective on sustainable development especially in developing regional international environmental law on sustainable development.

\section{The Road to Sustainable Development: Global Perspective}

When the World Commission on Environment and Development (WCED) announced its report through its publication entitled "Our Common Future", sustainable development became an important direction for world development at the time. This process can occur since the interests of development and the environment have been a prolonged problem especially since the Human Environment Conference in Stockholm, Sweden in 1972, which underscores the importance of an agreement between the environment and development through international legal norms. The important publication to follow up on the environmental and developmental position through carrying capacity published by United Nations Environmental Programme and Worldwildlife Fund (UNEP-WWF) was an interesting material to be discussed at that time.

On the other hand, international legal cases have laid the groundwork for the importance of sustainable development, such as the case of Behring Sea Fur Case (USA v. UK, Arbitration, 1893) and Gabcikovo Nagymaros Dam Project (Hungary v. Slovk, ICJ, 1993), and several other cases. (Marr, 2003, pp. 40-41). These international law cases want to show that sustainable development has become an essential part of any development activity/project/program.

Therefore, in 2000 at the Millennium Summit, states have affirmed its importance in the framework of global development through Millennium Development Goals (MDGs). Two years later in Johannesburg, South Africa emphasized a more focused commitment to sustainable development through the World Summit on Sustainable Development (WSSD). This summit provides direction for sustainable development and the importance of synchronization with the Millennium Development Goals (MDGs).

Currently MDGs have ended and replaced by Sustainable Development Goals (SDGs). The replacement process is also related to the important documents produced in the Rio Plus 20 Summit, which is the document 
"Future We Want”. This document makes one of the considerations for the Post-Agenda 2015. In the "Future We Want" document, sustainable development is a prerequisite for achieving prosperity of the human race. In September 2015, UN Summit has adopted 17 Sustainable Development Goals and 2030 Agenda for Sustainable Development.

In various sustainable development agreements reached at the global level, ASEAN also plays a role through its involvement in these meetings. Even the obligations that have been agreed upon in sustainable development are also affirmed by ASEAN, one of which is stated in ASEAN Declaration on Environmental Sustainability 2007 in Singapore:

Cognizant of mounting global concern over the environment and ASEAN's obligations to its people in fulfilling the aims of the World Summit on Sustainable Development (WSSD) and to achieve the UN Millennium Development Goals (MDGs), in particular to ensure environmental sustainability in the context of sustainable development.

Likewise in the ASEAN Yangon Resolution on Sustainable Development 2003 that strengthens ASEAN's commitment to the WSSD global agreement in Johannesburg, South Africa 2002:

Affirming that the Johannesburg Plan of Implementation of the World Summit on Sustainable Development (WSSD) provides an effective framework for international and regional cooperation based on the principle of common but differentiated responsibilities.

The declaration and resolution are non-legally binding soft laws, but have a strong and clear commitment to ASEAN towards a global commitment to sustainable development as such ASEAN has a shared view of the agreement reached at the global level on sustainable development.

\section{The Importance of Sustainable Development for ASEAN}

At the 9th ASEAN Summit in Bali, 2003, the ASEAN leaders adopted the Declaration of ASEAN Concord II or Bali Concord II in which they resolved that an ASEAN Community shall be established comprising three pillars, namely ASEAN Political-Security Community (APSC), ASEAN Economic Community (AEC), and ASEAN Socio-Cultural Community (ASCC). After that, in Kuala Lumpur, Malaysia the 27th ASEAN Summit adopted the ASEAN 2025: Forging Ahead Together, to chart the future direction of the ASEAN Community into the next decade. The "Forging Ahead Together" succeeds the roadmap for an ASEAN Community (2009-2015). The "Forgoing Ahead Together" document consists of the Kuala Lumpur Declaration on ASEAN 2025: Forging Ahead Together, the ASEAN Community Vision 2025, the ASEAN Political-Security Community Blueprint 2025, the ASEAN Economic Community Blueprint 2025, and the ASEAN Socio-Cultural Community Blueprint 2025.

Severino (2005) said that ASEAN has gained recognitions of a regional entity and has, to a rising degree, acted as one. Although according to Sridharan (2007), ASEAN has never aspired to become a supra-national organization. Recognizing the importance of environmental cooperation for sustainable development and regional integration, ASEAN has since 1977 cooperated closely in promoting environmental cooperation among its member states (ASEAN Secretariat, 2017b). Environmental awareness and environmental regionalism have evolved slowly and in three major phases (Elliott, 2011). In the first phase, ASEAN introduced the first sub regional environment program (ASEAN Environmental Programme (ASEP I) which mainly emphasized on securing the availability of natural resources for economic development. During the second phase (from the late 1980s until the late 1990s), the focus shifted to transnational threats. The third 
phase is characterized by the formation of formal relations within the community. In 1993, the ASEAN Senior Officials on the Environment (ASOEN) agreed to develop the ASEAN Strategic Plan of Action on the Environment. The new action plan should shift focus towards sustainable development strategies.

For ASEAN, sustainable development is a must that is an important part of Southeast Asian society development. The purpose of the establishment of ASEAN is the welfare of its people through three important pillars of politic-security, economy, and social culture. The ASEAN Community Vision 2025 recognizes the complementarity of the UN 2030 Agenda for Sustainable Development with ASEAN's Community building efforts to uplift the standards of living of her peoples. The UN 2030 Agenda for Sustainable Development clearly states that "sustained, inclusive and sustainable economic growth is essential for prosperity. This will only be possible if wealth is shared and income inequality is addressed".

The new ASEAN Socio-Cultural Community (ASCC) Blueprint 2025 has a strong emphasis on promoting and ensuring one layer protection, as well as developing and adapting environmentally-sound technology at all times. The term "sustainable" was a recurring theme throughout the 2025 Blueprint, from environmental protection, social development, consumption and production, to responding to natural disasters.

ASEAN environmental cooperation focuses on 10 priority areas, which range from promoting environmentally friendly technology and harmonizing policies and databases to promoting the sustainability levels of cities and urban areas and protecting the sustainability of freshwater sources.

ASEAN has four key result areas of "Sustainable" Characteristic in ASCC Blueprint 2025 and 10 priority areas of ASEAN Environmental Cooperation. Four key result areas are:

(1) Conservation and Sustainability Management of Biodiversity and Natural Resources;

(2) Environmentally Sustainable Cities;

(3) Sustainable Consumption and Production;

(4) Sustainable Climate.

Ten priority areas of ASEAN Environmental Cooperation are:

(1) Global Environmental Issues;

(2) Trans-boundary environmental pollution;

(3) Environmental Education;

(4) Environmentally Sound Technology;

(5) Environmentally Sustainable Cities;

(6) Environmental Policies and Databases;

(7) Coastal and Marine Environment;

(8) Nature Conservation and Biodiversity;

(9) Water Resources Management;

(10) Climate Change.

The other else, there are five key programmes including implementation of ASEAN Peat land Management Strategy including the five-year International Fund for Agricultural Development-Global Environment Facility (IFAD-GEF) project on rehabilitation of peat land forests in Southeast Asia, implementation of ASEAN Environmental Education Action Plan, development of ASEAN Guidelines on Eco-schools, and implementation of ASEAN Heritage Parks Programme, and ASEAN Environmentally Sustainable City Award Programme. 


\section{ASEAN's Documents on Sustainable Development}

ASEAN as a regional international organization has also played a role in the dynamics of global environmental issues. According to Severino (2005), ASEAN's founding document was a two-page "Declaration" as a Bangkok Declaration 1967. Most ASEAN agreements, even those that are technically binding, have been dependent on the voluntary compliance of member state. Sustainable development that has grown internationally is also followed by ASEAN with the agreements in a legally binding or non-legally binding. Even before "Our Common Future" was published by World Commission Environment and Development (WCED), ASEAN has agreed on the Manila Declaration on ASEAN Environment on 13th April, 1981. One item in this declaration confirms:

Further recognizing, that sustained development is dependent upon the continuous availability of natural resources.

The ASEAN Commitment was reaffirmed in the ASEAN Agreement on Nature and Natural Conservation in 1985. The ASEAN Commitment on sustainable development is underscored in the notion that:

Conscious also, that the inter-relationship between conservation and socioeconomic development implies both that conservation is necessary to ensure sustainability of development, and that socioeconomic development is necessary for the achievement of conservation on a lasting basis.

Then in Article 1(1), it is reaffirmed on the fundamental principle which states:

The Contracting Parties, within the framework of their respective national laws, undertake to adopt singly, or where necessary and appropriate through concerted action, the measures necessary to maintain essential ecological process and life-support systems, to preserve genetic diversity, and to ensure the sustainable utilization of harvested natural resources under their jurisdiction in accordance with scientific principles and with a view to attaining the goal of sustainable development.

Although ASEAN Agreement 1985 is still not entered into force, ASEAN still has a commitment to sustainable development. In further developments, ASEAN is strengthening itself in its commitment to sustainable development. This was further affirmed in the Jakarta Resolution on Sustainable Development signed by the ASEAN Minister of the Environment at the 3rd meeting on 30th October, 1987. In the consideration section of the Jakarta Resolution 1987, it is affirmed that:

Conscious that the sustainability of development requires that development processes and environmental management be conducted in an integrated manner.

This resolution also adopts the principle of sustainable development as stated in Section 1 of the resolution:

I. That ASEAN member countries adopt the principle of sustainable development to guide and to serve as an integrating factor in their common efforts.

In order to achieve this resolution especially in various ASEAN activities, the cooperation of various stakeholders is needed. This is stated:

III. That ASEAN cooperation should encompass governments and government agencies as well as the private business sector, professional associations, educational and academic institutions and non-governmental organizations. 
In addition, the Jakarta Resolution 1987 also emphasises that in achieving sustainable development, it is necessary to institutionalize this matter as stated:

V. That in affirming this Resolution, the ASEAN Environment Ministers are aware that the pursuit of sustainable development would be best served by the establishment of a regional body on the environment of sufficient stature whose task should include...

In 1990, ASEAN signed the Kuala Lumpur Accord and continued with some declaration and resolution, such as Jakarta Declaration on Environment and Development 1997 and Kota Kinabalu Resolution on the Environment 2000. In 2002, ASEAN agreed on regional treaty agreement, namely the ASEAN Agreement on Trans-boundary Haze Pollution was signed on 10th June, 2002 in Kuala Lumpur, Malaysia. In the same year, ASEAN stated Joint Statement of the Ministers Responsible for Environment of the Member States of ASEAN to the World Summit on Sustainable Development 2002. This statement is a support for the World Summit on Sustainable Development in Johannesburg, South Africa 2002.

In 2003, ASEAN agreed Yangon Resolution on Sustainable Development and 2006 Cebu Resolution on Sustainable Development. In 2007, ASEAN agreed on the ASEAN Declaration on Environmental Sustainability which confirmed several things including:

Cognizant of mounting global concern over the environment and ASEAN's obligations to its people in fulfilling the aims of the World Summit on Sustainable Development (WSSD) and to achieve the UN Millennium Development Goals (MDGs), in particular to ensure environmental sustainability in the context of sustainable development;

Reiterating the need to build an ASEAN Community that is economically vibrant and environmentally friendly, so that the present and future generations can enjoy a clean and sustainable environment.

The ASEAN Charter, signed in 2007, the opening section further emphasizes the importance of sustainable development:

ASEAN ... RESOLVED to ensure sustainable development for the benefit of present and future generations, and to place the well-being, livelihood and welfare of the peoples at the centre of the ASEAN community building process.

In the Chairman's Statement of the 28th and 29th ASEAN Summits at Vientiane, on 6th-7th September, 2016 in the theme: "Turning Vision Into Reality for a Dynamic ASEAN Community", there are two commitments on sustainable development. These commitments are:

86. We adopted the ASEAN Joint Statement on Climate Change to the 22nd Session of the Conference of the Parties to the United Nations Framework Convention on Climate Change (UNFCCC COP-22) and looked forward to fruitful outcomes of UNFCCC COP-22 in Marrakesh, Morocco in November 2016 in ensuring the successful implementation of Paris Agreement according to the principle of common but differentiated responsibilities, in light of different national circumstances and in support of sustainable development.

87. We adopted the ASEAN Joint Statement to the Thirteenth Meeting of the Conference of Parties to the Convention on Biological Diversity (CBD COP 13) which will be held on 4-17 December 2016 in Cancun, Mexico to articulate our commitments to the ASEAN 2025: Forging Ahead Together, the Strategic Plan for Biodiversity 2011-2020, and the 2030 Agenda for Sustainable Development in the conservation and sustainable management of biodiversity and natural resources.

Continuing commitment of sustainable development, ASEAN was results some agreed, such as ASEAN Declaration on Environmental Sustainability 2007, Singapore Resolution on Sustainability and Climate Change 2009, Joint Declaration on the Attainment of the Millennium Development Goals in ASEAN 2009, ASEAN Road Map for the Attainment of Millennium Development Goals (MDGs) 2011, Bangkok Resolution on 
Environmental Cooperation 2012, ASEAN Joint Statement on the Implementation on Sustainable Consumption and Production in ASEAN 2013, Declaration on ASEAN Post-2015 Environmental Sustainability, and Climate Change Agenda 2015.

In the document of Vientiane Declaration on Reinforcing Cultural Heritage Cooperation in ASEAN 2016, it has agreed:

Recognizing the 2030 United Nations Agenda for Sustainable Development Goals (SDG), which highlights the significant role of culture in two areas namely: (i) strengthening efforts to protect and safeguard the world's cultural and natural heritage and (ii) promoting a culture of peace and non-violence, global citizenship and appreciation of cultural diversity and of culture's contribution to sustainable development, both addressing tangible and intangible cultural heritage.

In the ASEAN Joint Statement to the Thirteenth Meeting of the Conference of Parties to the Convention on Biological Diversity (CBD COP 13), it has statement:

Reaffirming our commitment to implement the Strategic Plan for Biodiversity 2011-2020 and achieve the Aichi Biodiversity Targets; and to the 2030 Agenda for Sustainable Development and its Sustainable Development Goals (SDGs), in particular Goals 14 and 15 on the conservation and sustainable use of coastal and marine resources, and terrestrial ecosystems respectively;

Welcoming the recommendations of the ASEAN Conference on Biodiversity with the theme "Biodiversity for Sustainable Development” held on 15-19 February 2016 in Bangkok, Thailand which included the need to accelerate actions, mainstream biodiversity issues, strengthen partnerships and increase financing to address the region's biodiversity-related challenges.

In the ASEAN Joint Statement on Climate Change to the 22nd Conference of the Parties (COP-22) to the United Nations Framework Convention on Climate Change (UNFCCC), it has stated:

Further Reaffirming that efforts to address climate change should be consistent with broader Sustainable Development Goals (SDGs).

After that, it has agreed:

6. Continue to explore means of further enhancing sustainable development efforts in the region under the CBDR principles as entrenched in the Convention;

11. Request support for developing countries and least developed countries to pursue sustainable development opportunities that can enable mitigation and adaptation efforts to be included in their (I) NDCs as appropriate, noting that mitigation and adaptation efforts can have strong regional co-benefits which contribute, inter alia, to food, water, energy security and local culture.

ASEAN Foreign Ministers' Statement on the Developments in the Korean Peninsula on 5th August, 2017 has agreed:

We strongly call upon the DPRK, as a participant of the ASEAN Regional Forum, to positively contribute to realize the ARF Vision to maintain the Asia-Pacific as a region of lasting peace, stability, friendship and prosperity where States and organizations, both within and outside the region work in a spirit of mutual trust, appreciation and respect to overcome security threats and challenges and prevent escalation of potential conflicts with a view to creating an environment conducive to sustainable development, social progress and improved quality of life for all peoples in the region.

In the ASEAN Joint Declaration on Hazardous Chemicals and Wastes Management on 26th April, 2017, it has agreed that:

Recalling the ASEAN Vision of 2020 that envision a clean and green ASEAN with fully established mechanisms for 
sustainable development to ensure the protection of the region's environment, the sustainability of its natural resources, and the high quality of life of its people

The other statement has:

Acknowledging, the global commitment and targets of the 2030 Agenda for Sustainable Development particularly on Goal 12 Ensuring Sustainable Consumption and Production Pattern.

Adhering the purposes of ASEAN enshrined in Article 1 of the ASEAN Charter, that is to promote sustainable development so as to ensure the protection of the region's environment, the sustainability of its natural resources, the preservation of its cultural heritage and the high quality of life of its people.

Call upon non-ASEAN Member State Parties particularly developed Parties to the Basel Convention, Rotterdam Convention, and Stockholm Convention to strengthen and deepen the cooperation with ASEAN towards the full implementation of the conventions.

In the Chairman's Statement 30th ASEAN Summit Manila on 29th April, 2017 with theme: "Partnering for Change, Engaging the World”, it has statement:

99. We welcomed the signing of two ASEAN-EU programmes on sustainable use of peat lands and haze mitigation in ASEAN as well as biodiversity conservation and management of protected areas in ASEAN.

101. We reaffirmed our commitment to the conservation and sustainable management of biodiversity and natural resources in the ASEAN region. We looked forward to the full ratification of the ACB Establishment Agreement.

102. We noted the successful conduct of the Fifth ASEAN Heritage Parks Conference with the theme, "Innovations for Enhanced Governance of ASEAN Heritage Parks,” on 24-27 October 2016 in Nay Pyi Taw, Myanmar that brought together various actors of the ASEAN Heritage Parks Programme to review and exchange views on the progress of ASEAN's efforts in effectively managing ASEAN Heritage Parks and addressing biodiversity issues for sustainable development.

\section{ASEAN With Dialogue Partner and External Partner in the Commitment of Sustainable Development}

ASEAN's relations with dialogue partners and external partners have been fortified and deepened in the past one year through bolstering the existing frameworks and implementing the plans of action that are in line with the ASEAN Community Vision 2025 (ASEAN Secretariat, 2017a). In the cooperation on sustainable development, there are some commitments with dialogue partner. The commitments are:

\section{ASEAN-Australia}

The first ASEAN-Australia cooperation in 1974 has started through ASEAN-Australia Dialogue Relations Towards a Strategic Partnership for Mutual Benefit. The Plan of Action (POA) builds upon the strong cooperation between ASEAN and Australia. In 2015 Plan of Action agreed to implement the ASEAN-Australia Strategic Partnership (2015-2019). This POA is to implement the goals and objectives of the ASEAN-Australia Summits and the Joint ASEAN-Australia Leaders' Statement on the 40th Anniversary. In this programme there is support cooperation that builds the institutional capacity of AANZFTA (ASEAN-Australia-New Zealand Free Trade Agreement) Parties and the ASEAN Secretariat and contributes to sustainable development outcomes; support and promote conservation and sustainable management of ASEAN's coastal and marine environment.

\section{ASEAN-Canada}

The first dialogue ASEAN-Canada has started in the year on 1977. After this dialogue, there are some meeting and joint activities. Recently, in June 2006 at Bandar Seri Begawan, Brunei, the ASEAN-Canada has 
agreed to a Joint Cooperation Work Plan that was being drawn up as a basis for future cooperation. In the Joint Declaration Between ASEAN and Canada on Trade and Investment Jakarta, Indonesia, 3rd October, 2011, the declaration desires to ensure that trade and environmental policies are mutually supportive in the furtherance of sustainable development. In the Co-Chairs' Press Statement of the ASEAN-Canada Commemorative Summit on the Occasion of the 40th Anniversary of the Establishment of ASEAN-Canada Dialogue Relations at Manila, Filipina on 14th November, 2017, the statement has reaffirmed the important role played by ASEAN and Canada in building up the political-security, economic, socio-cultural, and people-to-people agenda of the Asia Pacific region and agreed to continue strengthening our enhanced partnership for mutual benefit and in support of global peace, security, prosperity, and sustainable development.

\section{ASEAN-China}

The first contact ASEAN-China was conducted in 1990. After this contact, there are some joint activities in the environmental and sustainable development aspects. At Ha Noi, Viet Nam, on 29th October, 2010, the ASEAN-China has agreed Leaders' Joint Statement on Sustainable Development. In June 2016, the ASEAN-China Strategy on Environmental Cooperation (2016-2020) was endorsed by the ASEAN-China leader. The overall objective of the ASEAN-China Strategy on Environmental Cooperation (2016-2020) is to strengthen ASEAN-China cooperation in priority areas of environmental protection by taking a coordinated and integrated approach with a view to achieving environmental sustainability in the region. The others else of this program is to implement the ASEAN-China Cooperation Framework for Environmentally Sound Technology and Industry by building up a platform for information exchange, conducting demonstration projects, and developing joint research on environmental technology, in support of the 10-Year Framework on Sustainable Consumption and Production.

\section{ASEAN-European Union}

In the 7th March, 1980 at Kuala Lumpur, Malaysia has signed Cooperation Agreement between Member Countries of ASEAN and European Community. The Article 3 stated the cooperation in the fields of science and technology, energy, environment, transport and communications, agriculture, fisheries and forestry. In the environmental field, there is a program for sustainable development achievement. ASEAN and the EU launched two new programmes in March 2017 to further strengthen ASEAN-EU cooperation in environmental protection and sustainable development, namely, the Sustainable Use of Peat Land and Haze Mitigation in ASEAN and the Biodiversity Conservation and Management of Protected Areas in ASEAN region. EU has also supported an ASEAN Regional Centre for the Biodiversity Conservation. In the Co-Chairs' Statement of the 20th EU-ASEAN Ministerial Meeting at Brussels, Belgium, 23rd July, 2014, the ministers supported the inclusive and transparent approach of the Post-2015 Sustainable Development Agenda formulation process. They welcomed the proposal of the Open Working Group for Sustainable Development Goals and the recommendations of the High Level Panel on the Post-2015 Development Agenda. The ministers also emphasised that the objectives of the new universal framework should reinforce the international community's commitment to poverty eradication and sustainable development. In celebrating the 40th anniversary of their partnership, ASEAN-EU has statement on the Paris Agreement on reaffirming commitment to cooperation to address the shared challenge of climate change. It has agreed to reaffirm our commitment to work together with all stakeholders to combat climate change and its impacts, consistent with the broader outcomes and goals of the 2030 Agenda for Sustainable Development and the Paris Agreement. 


\section{ASEAN-India}

The first dialogue ASEAN-India in 1990. After that dialogue, India became dialogue partnership formally in 1992. There is Plan of Action to Implement the ASEAN-India Partnership for Peace, Progress and Shared Prosperity (2010-2015) that ASEAN-India has agreed to intensify ASEAN-India development cooperation in support of ASEAN efforts in achieving the Millennium Development Goals (MDGs). In 2012 India became strategic partnership of ASEAN. The Plan of Action Dialogue Partnership focuses on security, economy, society, and culture. There are five key areas of cooperation including connectivity, blue economy, digital age, migration, and soft power (Chapman, 2018, p. 2). In the blue economy one emphasizes the importance of sustainable development. The 2017 India-ASEAN cooperation is to strengthen ASEAN solidarity by working together through environmental and sustainable development programs (en.nhandan.com.vn/politics/editor).

\section{ASEAN-Japan}

ASEAN-Japan Summit in the first time has held in 1977. After the summit, some dialogue and summit was held and developed. For example, The Sixteenth Consultations between the ASEAN Economic Ministers (AEM) and the Minister for Economy, Trade and Industry (METI) of Japan (16th AEM-METI Consultations) was held in Da Nang, Viet Nam on 26th August, 2010. The ministers expressed appreciation on Japan's commitment to promote the "Asian Sustainable Chemical Safety” Plan. The technical cooperation on personnel training and ASEAN and East Asia (ERIA) research on chemical management system in ASEAN and East Asia would contribute in developing sustainable society in the region. In the Chairman's Statement of the 13th ASEAN-Japan Summit at Ha Noi, Viet Nam on 29th October, 2010, the summit reiterated the importance of sustainable development, including energy efficiency and energy conservation for sustainable development and in this regard appreciated Japan's initiatives, such as the Smart Community Initiative and the Asian Sustainable Chemical Safety Plan. In the Chairman's Statement of the 17th ASEAN-Japan Summit Nay Pyi Taw, Myanmar on 12th November, 2014, the summit looked forward to sharing scientific and technological know-how and expertise on environmentally friendly technology in order to achieve low carbon growth in the region, one of the key elements to achieving sustainable economic growth. In the Chairman's Statement of the 20th ASEAN-Japan Summit on 13th November, 2017, Manila, Philippines with theme "Partnering for Change, Engaging the World”, the summit has noted the continued growth of cooperation on environmental issues, particularly in addressing issues relating to environmental protection and sustainable development. In this regard, the ASEAN leaders welcomed the ASEAN-Japan Environmental Cooperation Initiative which aims to advance environmental cooperation in areas including climate change, waste management, biodiversity conservation, chemical pollution management, wastewater management, and quality environmental infrastructure development for sustainable cities, as well as cooperation in Sustainable Development Goals (SDGs).

\section{ASEAN-Republic of Korea (ROK)}

ASEAN-ROK relation was elevated to full dialogue status in 1991. In the Joint Declaration on ASEAN-Republic of Korea Strategic Partnership for Peace and Prosperity at Ha Noi, Viet Nam on 29th October, 2010, there are some cooperation and commitments on sustainable development. These cooperation and commitments are to enhance ASEAN-ROK cooperation in environmental management including integrated water resource management; environmentally sustainable cities; environmentally sound technologies and cleaner production; biodiversity conservation; public awareness and education; sustainable use of coastal 
and marine environment and trans-boundary environmental pollution. And other else is to strengthen ASEAN-ROK cooperation on programes to mitigate and address the impact of climate change and promote sustainable development. In the Chairman's Statement of the 19th ASEAN-ROK Summit on 13th November, 2017 at Manila, Philippines with theme: "Partnering for Change, Engaging the World", the summit looked forward to further cooperation in the area of sustainable development, including the sharing of ROK's experience in combining rapid economic growth with poverty reduction, clean energy, green growth, and ICT (information communications technology) in pursuit of ASEAN's economic integration and poverty alleviation.

\section{ASEAN-New Zealand}

New Zealand became ASEAN's dialogue partner in 1975. The partnership between ASEAN and New Zealand reached a significant milestone with the adoption of the ASEAN-New Zealand Joint Declaration on Comprehensive Partnership for 2015 and the Plan of Action to Implement the Joint Declaration at the PMC +1 Session with New Zealand on 22nd July, 2010 in Ha Noi. New Zealand regularly attends the East Asia Summit (EAS) Environmental Track Senior Official Meeting or SOM to strengthen links between New Zealand and ASEAN in areas of mutual interest, such as biodiversity conservation, natural resources management, green technology development, environmental governance, sustainable development, chemicals and hazardous wastes control, sustainable forest management, and climate change. Together with several ASEAN Member States, New Zealand is also a member of the Asia Pacific Carbon Market Roundtable (APCMR) Forum. (http://asean.org/storage/2012/05/Overview-ASEAN-New-Zealand-DR_as-of-April-2017.pdf).

\section{ASEAN-Russia}

Since 1991 the foreign minister of ASEAN and the Soviet Union has had several consultative meetings. In October 1994 the Russian Federation suggested the establishment joint committee. For example, recently, at the Russian Federation-ASEAN Leaders' Statement on Sustained Recovery and Development, was adopted in Ha Noi, on 9th April, 2010 has welcomed the Russian Federation's support for the ASEAN's efforts to enhance regional connectivity which will promote future peace and prosperity in the region. ASEAN welcomed the participation of the Russian Federation in the regional integration processes, considering it as an important factor of stability and sustainable development in the Asia-Pacific. It has determined to expand cooperation and collaboration with all interested partners with a view to building long-lasting peace, stability, and security in the region and create favorable conditions for global sustainable development in the interests of the international community.

\section{ASEAN-United States (US)}

In the Joint Press Statement of the 16th US-ASEAN Dialogue at Washington DC on 29th November, 2001, the dialogue had commitment on environmental and sustainable development in making the World Summit on Sustainable Development in Johannesburg 2002 a success. In the 11th Meeting of the Conference of the Parties to the Convention on Biological Diversity (CBD), US-ASEAN has agreed on Joint Statement of the ASEAN Environment Ministers in promoting the aim to ensure conservation and sustainable management of ASEAN biodiversity towards enhancing social and economic, and environmental well-being. In the Chairman's Statement of the 5th ASEAN-US Summit to Commemorate the 40th Anniversary of ASEAN-US Dialogue Relation on 13th November, 2017 at Manila, Philippines with theme "Partnering for Change, Engaging the World”, the summit expressed continued support for the Lower Mekong Initiative, which assists ASEAN in advancing sustainable development, narrowing development gaps, and promoting regional connectivity and in 
this connection, underscored the importance of promoting cooperation in sustainable development.

\section{ASEAN-Plus Three}

The ASEAN Plus Three (APT) cooperation process began in December 1997 with the convening of an Informal Summit among the leaders of ASEAN and China, Japan, and the ROK at the side lines of the Second ASEAN Informal Summit in Malaysia. APT Cooperation has developed Strategy Framework, especially on food security and bio-energy, climate change mitigation and adaptation, sustainable forest management, agricultural research and development, and human resource development. In the Chairman's Statement of the 16th ASEAN Plus Three Summit at the Bandar Seri Begawan, Brunei Darussalam on 10th October, 2013, the leaders have agreed especially Part 16 Chairman's Statement. Part 16 said that we recognized the increasing need to facilitate closer cooperation on environment and sustainable development and hence welcomed the convening of the 12th ASEAN Plus Three Environment Ministers' Meeting held in Surabaya, Indonesia on 26th September, 2013. The statement also welcomed the proposal to hold the 2nd ASEAN Plus Three Youth Environment Forum with the theme "Youth and Sustainability" in Bandar Seri Begawan, Brunei Darussalam in November 2013. In the Chairman's Statement of the 20th ASEAN Plus Three Commemorative Summit on 14th November, 2017 at Manila, Philippines with theme "Partnering For Change, Engaging the World", the leaders have agreed to adopt the APT Leaders' Statement on Food Security Cooperation and reaffirmed our commitment to work together to ensure food security, food safety, better nutrition, and equitable distribution as well as promote sustainable development in the region.

\section{ASEAN-Norway}

The cooperation of ASEAN-Norway has started by accession of Norway to the Treaty of Amity and Cooperation (TAC) in Southeast Asia on 1st July, 2013 in Bandar Seri Begawan, Brunei Darussalam. In first the Joint Statement on ASEAN-Norway Partnership at Nay Pyi Taw, Myanmar, on 8th August, 2014, the statement sought ways and means to support private-public collaboration that promotes sustainable agricultural commodity production. Statement was also to strengthen socio-cultural cooperation in support of the implementation of the ASEAN Socio-Cultural Community (ASCC) Blueprint as well as the implementation of the ASEAN Roadmap for the Attainment of the Millennium Development Goals (MDGs).

\section{ASEAN-Switzerland}

Switzerland became as ASEAN sector ASEAN partner at the 49th ASEAN Ministerial Meeting or AMM in Vientiane, Laos, in August 2016. Switzerland is the 3rd sector partner of ASEAN after Pakistan and Norway. The 2nd ASEAN Meeting Joint Sectoral Cooperation was held in the ASEAN Secretariat, Jakarta on 15th December, 2017. This meeting noted the good progress made in cooperation since Switzerland was conferred the status of ASEAN's sectoral dialogue partnership in July 2016. A plan is being developed on Practical Cooperation Areas 2017-2021 with a view to supporting the implementation of the ASEAN Community Vision 2025 and achieving the UN Sustainable Development Goals.

\section{ASEAN-Pakistan}

Pakistan was accorded the status of sectoral dialogue partner of ASEAN at the 26th ASEAN Ministerial Meeting on 23rd July, 1993. The inaugural meeting of ASEAN-Pakistan Joint Sectoral Dialogue Relations was convened on 5th-7th November, 1997 in Islamabad to launch the partnership. ASEAN and Pakistan have undertaken cooperation in trade, industry and investment, science and technology, drugs and narcotics control, 
environment sustainable development, tourism, and human resources development

\section{ASEAN-Germany}

Germany was conferred the status of development partner of ASEAN by the 49th ASEAN Foreign Ministers' Meeting (AMM) on 24th July, 2016 in Vientiane, Lao PDR. The ASEAN-Germany Development Partnership was institutionalized through the convening of the First ASEAN-Germany Development Partnership Committee (AG-DPC) Meeting on 23rd January, 2017 at the ASEAN Secretariat, Jakarta. A Programme on "Protection of Biological Diversity in the ASEAN Member States in Cooperation with the ACB” was launched in April 2015, which aims to protect the biological diversity, promote the sustainable management of natural ecosystems, and improve the livelihoods of local population in the ASEAN region. In the future cooperation, ASEAN-Germany has developed some programs such as technical and skills training, tourism, green and renewable energy, sustainable development, promotion of small and medium industries, humanitarian assistance and disaster relief, support for the implementation of the Master Plan on ASEAN Connectivity (MPAC 2025) and the Initiative for ASEAN Integration (IAI) Work Plan III.

\section{ASEAN-United Nations}

ASEAN-UN has a Joint Declaration on Comprehensive Partnership between ASEAN and the UN, which was adopted by the leaders of ASEAN and the UN Secretary-General at the 4th ASEAN-UN Summit on 19th November, 2011 in Bali, Indonesia. Through the implementation of this Plan of Action, both sides will also work together to support the realization of the ASEAN 2025: Forging Ahead Together and the global 2030 Agenda for Sustainable Development in a complementary manner and to strengthen collaboration in jointly addressing emerging regional and global challenges. In this Plan of Action there are some programs including support ASEAN in achieving peaceful and inclusive societies for sustainable development, providing access to justice for all, and building effective, accountable, and inclusive institutions through the 2030 Agenda for Sustainable Development; promote cooperation and collaborative efforts through joint development and implementation of the ASEAN-UN Environment and Climate Change Action Plan 2016-2020 towards the realization of the ASEAN Declaration on ASEAN Post-2015 Environmental Sustainability and Climate Change Agenda as well as the 2030 Agenda for Sustainable Development and the 2015 Paris Agreement on Climate Change; in the other else, support ASEAN's efforts in promoting the integration of Sustainable Consumption and Production strategies and best practices into national and regional policies or as part of Corporate Social Responsibility (CSR) activities as well as ASEAN's efforts for sustainable urban development including promoting integrated resource management; strengthen collaboration for enhancing the well-being and livelihood of the peoples in the region through sustainable development and poverty eradication; promote the exchange of best practices, technical cooperation, and capacity building in monitoring and reporting on Sustainable Development Goals; explore new partnerships to harness the private sector's financial and nonfinancial resources, science, technology, and innovation needed to implement the 2030 Agenda for Sustainable Development. In the Chairman's Statement of the 9th ASEAN-United Nations Summit on 13th November, 2017 at Manila, Philippines, the statement has looked forward to policy conversations at the technical level on how ASEAN Economic Community (AEC) can support and contribute to the achievement of the Sustainable Development Goals, primarily through the impact evaluation component of the AEC 2025 Monitoring \& Evaluation Framework in realizing the vision of a people-centered and people-oriented ASEAN.

\section{East Asia Summit}


East Asia Summit (EAS) cooperation is progressing well in the six priority areas: energy, education, finance, global health issues and pandemic diseases, environment and disaster management, and ASEAN connectivity. Recently, in 2010 at the East Asia Summit, the foreign minsiters has agreed on Chairman's Statement of the East Asia Summit Foreign Ministers Informal Consultations at Ha Noi, Viet Nam, on 21st July, 2010 that affirmed the context of global uneven and risk-prone economic recovery. The ministers also were of the view that the EAS participating countries can play an important role in the region's efforts in restoring financial stability and generating sustainable economic growth and development, and in further enhancing regional financial cooperation.

\section{ASEAN-Gulf Cooperation Council (ASEAN-GCC)}

In the Joint Press Statement of the 2nd ASEAN-GCC Ministerial Meeting Singapore on 1st June, 2010, the statement stressed the need for greater international cooperation to address the serious challenges of climate change and the environmental deterioration that have had negative effects on socio-economic development. In particular, we encouraged developed countries to support developing countries with adequate, predictable, and sustainable financial resources, transfer of technology, as well as capacity enhancement to enable mitigation and adaptation efforts by developing countries through effective institutional arrangements.

\section{ASEAN-Pacific Alliance (PA)}

The ASEAN-PA Framework for Cooperation was adopted at the 3rd ASEAN-PA Ministerial Meeting in September 2016 in New York at the side lines of the UN General Assembly. The framework aims to enhance cooperation based on mutual interest and to bring relations closer in the some areas including sustainable development.

\section{ASEAN-Europe Meeting (ASEM)}

The Chair Statement Strengthening Partnership for Peace and Sustainable Development, in 13th ASEM Foreign Ministers’ Meeting on 20th-21st November, 2017 at Nay Pyi Taw, Myanmar, has reaffirmed ASEM's cardinal values of equal partnership, mutual respect, and mutual benefit. The ministers emphasized the need for closer engagement towards a stronger and more dynamic partnership in the process of addressing global issues and the creation of a favorable environment for a stronger, more sustainable and balanced development. The ministers underscored their firm commitment to promote and develop a stronger, more effective and fair international system with the United Nations at its core and effective multilateral institutions for cooperation. The ministers' statement has also underlined that the 2030 Agenda for Sustainable Development represents a breakthrough in the international community's collective approach towards achievement of sustainable development by 2030. They underscored the need for all stakeholders to work on ambitious and integrated implementation, including the Addis Ababa Action Agenda on Financing for Development, domestically as well as internationally. The ministers recalled the outcome of the 11th ASEM Summit and reaffirmed their commitment to the ASEM Tangible Cooperation Areas, which advance the 2030 Agenda in the ASEM Context. The ministers' statement also expressed concern over negative impacts of climate change, environmental degradation, and natural disasters on the sustainable development of ASEM partners. The ministers recognised the role of strong political commitment to the full and swift implementation of the Paris Agreement in coherence with the principle of common but differentiated responsibilities and respective capabilities, in the light of different national circumstances in order to foster climate resilience and low greenhouse gas emissions. 


\section{ASEAN-Other Organization}

ASEAN has also cooperated with the World Health Organization (WHO), United Nations Environmental Programme (UNEP), United Nations Educational, Science and Cultural Organization (UNESCO), United Nations Development Programme (UNDP), and other else, such as, ILO (International Labour Organization), UNICEF (United Nations International Children's Emergency Fund), UNAIDS, UN Office Drugs and Crime, etc. All of these organizations have conducted activities on sustainable development with ASEAN.

\section{The Influence of Sustainable Development in Regional International Environmental Law in ASEAN}

There are three pillars of sustainable development that are economic, social, and environment. Sustainable development has also relations with present and future generation. According the WCED (1987), sustainable development is defined:

Sustainable development is development which meets the needs of the present without compromising the ability of future generations to meet their own needs.

Sustainable development is a global concept. There are some principles of sustainable development, such as principle of environmental protection, principle of public participation, principle of access to information, precautionary principle, etc.

As a global concept, sustainable development has applied by ASEAN's norms and principles. ASEAN's clarity and commitment to sustainable development has been demonstrated in various legal documents, both hard law and soft law. Pramudianto (2017, p. 269) affirmed that ASEAN to date has succeeded in developing international environmental law through soft law and hard law. ASEAN has affirmed that commitment on sustainable development in various levels of regional international law, starting from documents that are legally binding and non-legally binding. But to do this, realization is required through programs and activities. Several programs and activities that emphasize the importance of sustainable development have been implemented at the national level.

As an example of sustainable development activities through the ASEAN Environmentally Sustainable City Award Program, it has provided incentives for ASEAN member countries, especially the ASEAN cities to make sustainable cities. This award is able to positively affect cities to improve governance through sustainable governance.

Studies claimed that the so-called "ASEAN Way" with its "principles of non-interference, consultation, consensus, quiet diplomacy, symbolism, and organizational minimalism” lessened the control powers of the ASEAN, particularly in terms of its efforts to address environmental challenges (Nguitragool, 2011, pp. 356-378; Macarayan et al., 2013, p. 2). The principle of non-interference and safeguarding member states' sovereignty is continued at the cost of the environment (Koh \& Robinson, 2002, p. 679). While ASEAN environmental programmes and agreements are highly ambitious in their wording, they often lack effective implementation and enforcement mechanisms. As a member state faces no serious consequences in the case of non-compliance, incentives for implementation and enforcement are low (Aggarwal \& Chow, 2010).

But, Ibitz (2012) in his research field of hazardous waste said that there is a strong need to establish ASEAN community law to govern the association with principles that can be applied at the national level. Without the adoption of a binding community law, ASEAN will not be able to develop into an effective and 
successful community.

Although there is "ASEAN Way", but the practice use of sustainable development has been generally accepted by ASEAN countries. This is evidenced by the agreement of documents of soft law and hard law that emphasize the importance of the concept of sustainable development and is used in many national laws in ASEAN countries. For example in Indonesia, there is Act Number 32 Year 2009 on Environmental Protection and Management. The part of consideration has affirmed that national economic development as such is mandated by the State Constitution Republic of Indonesia Year 1945 held based on the principle of sustainable development and environmentally friendly.

\section{Conclusion}

ASEAN has committed itself to its vision to fulfill sustainable development including implemented by its member countries. ASEAN cooperation with full partners and non-full partners has been done since long including in developing the concept of sustainable development.

The history of the founding of ASEAN is inseparable from the efforts to improve the welfare of the people of Southeast Asia which has now merged in the ASEAN Community since the ASEAN Charter 2007 was applied. ASEAN and sustainable development commitments as one of the vision of ASEAN, it is expected to improve the life of ASEAN countries whose past role conflicts.

Sustainable development will be an important vision in the ASEAN Community so much encourages the quality of life of ASEAN communities. This encouragement can be seen through ASEAN programs such as sustainability cities. On the other hand, ASEAN documents that have encouraged sustainable development will enhance the role of law, especially regional international environmental law.

Regional International Environmental Laws related to sustainable development are expected to flourish in Southeast Asia. This will be in accordance with Principle 27 of the Rio Declaration of 1992 which states the need for development of international sustainable development law. This principle affirms that:

States and people shall co-operate in good faith and in a spirit of partnership in the fulfillment of the principles embodied in this Declaration and in the further development of international law in the field of sustainable development.

In order to development of the sustainable development concept, regional international environmental law must take a initiative and implementation in regional of sustainable development law that must be applicable with ASEAN principles and norms.

\section{References}

Aggarwal, V. K., \& Chow, J. T. (2010). The perils of consensus: How ASEAN meta-regime undermines economic and environmental cooperation. Review of International Political Economy, 17(2).

ASEAN Secretariat. (2017a). ASEAN Annual Report 2016-2017: Partnering for change, engaging the world. Retrieved from http://asean.org/?static_post=partnering-change-engaging-world

ASEAN Secretariat. (2017b). ASEAN cooperation on environment: At a glance. Retrieved from http://asean.org/storage/2018/02/50.-December-2017-ASEAN-Cooperation-on-Environment-At-A-Glance.pdf

Chapman, T. (2018). ASEAN and India: Five for the next five (ORF Special Report No. 57). Retrieved from https://www.orfonline.org/wp-content/uploads/2018/01/ORF_SpecialReport_57_ASEAN-New.pdf

Elliott, L. (2011). ASEAN and environmental governance: Rethinking networked regionalism in Southeast Asia. Procedia Social and Behavioral Sciences, 14, 61-64.

Flores, J. M. (2000). ASEAN: How it works. Jakarta: ASEAN Secretariat. 
Ibitz, A. (2012). Environmental policy coordination in ASEAN: The case of waste from electrical and electronic equipment. ASEAS-Austrian Journal of South-East Asian Studies, 5(1), 30-51.

Koh, K. L., \& Robinson, N. A. (2002). Strengthening sustainable development in regional intergovernmental governance: Lessons from the ASEAN way. Singapore Journal of International and Comparative Law, 640-682.

LIN, C. H. (2010). ASEAN Charter: Deeper regional integration under international law? Chinese Journal of International Law, 9(49), 821-837.

Macarayan, E. R. K., Melisa, C., \& Mark, W. (2013). The Southeast Asian politics of natural resource use: Impacts on food and health inequalities. Paper presented at Australia Political Studies Association Conference, Murdoch University, Perth.

Marr, S. (2003). The precautionary principle in the law of the sea: Modern dicision making in international law. The Hague/London/New York: Martinus Nijhoff Publisher.

Nguitragool, P. (2011). Negotiating the haze treaty. Asian Survey, 51(2), 356-378.

Pramudianto, A. (2017). Hukum lingkungan internasional. Depok: CV Rajawali.

Pramudianto, A. (2016). Indonesia position in regional development international environmental law in ASEAN. Presentation in the 1st Asian Reseracher Symposium, University of Indonesia, Depok.

Sabir, M. (1992). ASEAN: Harapan dan kenyataan. Jakarta: Pustaka Sinar Harapan.

Severino, R. (2005). Framing the ASEAN charter: An ISEAS perspective. Singapore: ISEAS Publication.

Severino, R. (2006). Southeast Asia in search of an ASEAN Community. Singapore: ISEAS Publication.

Sridharan, K., \& Srinivasa-Raghavan, T. C. A. (2007). Regional cooperation in the South Asia and Southeast Asia. Singapore: ISEAS Publication. Retrieved from http://asean.org/storage/2012/05/Overview-ASEAN-New-Zealand-DR_as-of-April-2017.pdf

\section{Documents}

ASEAN Documents Series 2008, ASEAN Secretariat, Jakarta ASEAN Documents Series 2009, ASEAN Secretariat, Jakarta ASEAN Documents Series 2010, ASEAN Secretariat, Jakarta ASEAN Documents Series 2011, ASEAN Secretariat, Jakarta ASEAN Documents Series 2013, ASEAN Secretariat, Jakarta ASEAN Documents Series 2014, ASEAN Secretariat, Jakarta ASEAN Documents Series 2015, ASEAN Secretariat, Jakarta ASEAN Documents Series 2016, ASEAN Secretariat, Jakarta 